\title{
Supplementation of mixed roughage-based diet with rumen protected methionine for lactating goats
}

\author{
M. Urbaniak ${ }^{1}$, A. Gut ${ }^{2}$, H. Król' ${ }^{1}$, B. Zawadzka ${ }^{1}$, M. Kulik ${ }^{1}$, \\ A. Frankiewicz ${ }^{1}$ and A. Lyczyński ${ }^{3}$
}

${ }^{\prime}$ Department of Animal Nutrition and Feed Management,

${ }^{2}$ Department of Sheep and Goat Breeding,

${ }^{3}$ Department of Animal Origin Materials, August Cieszkowski Agricultural University

Wotyńska 33, 60-637 Poznań, Poland

\section{ABSTRACT}

Twenty goats of White Improved breed were divided by analogue method into four groups and fed a basal diet consisting of different roughages (maize silage, sugar beets and meadow hay) and a concentrate containing soyabean and rapeseed meals. Animals from individual groups were supplemented with $0,1.5,3$ and $4.5 \mathrm{~g} / \mathrm{d}$ of rumen protected methionine (Smartamine ${ }^{\mathrm{TM}} \mathrm{M}$ ).

No significant differences in milk yield and composition were observed. However, a trend in the daily milk and fat yields as well as in milk protein content and yields were found in goats with the increase of rumen protected methionine up to $3 \mathrm{~g} / \mathrm{d}$. The amino acid composition of milk protein did not differ significantly among groups.

KEY WORDS: lactating goats, protected methionine, milk yield, milk composition

\section{INTRODUCTION}

Methionine (Met) is considered as one of the most important amino acids (AA) limiting milk protein synthesis in lactating dairy cows (Rulquin et al., 1993; Sloan, 1997). In many investigations, in which the effect of Met infused postruminally or intravenously or fed in a rumen-protected form on milk yield and composition, differing results were obtained. In some cases, a simultaneous increase in milk and protein yield was observed (La Henaff et al., 1990; Rulquin and Delaby, 1997), in others - only in milk protein yield (Rulquin, 1992), while in many others - no effects were recorded (Pacheco-Rios et al., 1997; Overton et al., 1998). 
Relatively little is known about Met requirements of lactating goats and the few studies in this field deal mainly with metabolic aspects associated with protein synthesis in the mammary gland (Bequette et al., 1996).

Therefore, the purpose of our study was to determine the effect of different levels of rumen-protected methionine (RPM) on milk yield and its composition in lactating goats fed mixed roughage-based diet.

\section{MATERIAL AND METHODS}

Twenty goats of White Improved breed of average body weight $53 \mathrm{~kg}( \pm 4 \mathrm{~kg}$ ) were divided into four groups according to the analogue method. Standard criteria were used: lactation number (2-4), lactation stage (80-100 d) and milk yield (1.7$2.0 \mathrm{l} / \mathrm{d}$ ). The experiment consisted of a 14-day initial period and a 14-day experimental period in which animals from individual groups were supplemented with rumen protected DL-methionine (Smartamine ${ }^{\mathrm{TM}} \mathrm{M}$ ) containing $70 \%$ DL-methionine (Rhone-Poulenc Animal Nutrition, Poland) in the amount of 0, 1.5, 3.0 and $4.5 \mathrm{~g} / \mathrm{d}$.

Throughout the study, goats were housed in four groups and fed according to the INRA system (INRA, 1989). Animals obtained a basal ration consisting of mixed roughage and concentrate (69:31\%, DM basis). The roughage was made up of maize silage, sugar beets and meadow hay $(32: 13: 55 \%$, DM basis of all roughages) which were fed to animals in group in the amount of $1.3,1.3$ and $0.8 \mathrm{~kg} / \mathrm{d}$, respectively. The concentrate in the amount of $0.64 \mathrm{~kg} / \mathrm{d}$ (soyabean meal $12.92 \%$, rapeseed meal $9.23 \%$, wheat $9.23 \%$, wheat brans $27.68 \%$, barley $18.45 \%$, dried sugar beet pulp $18.45 \%$, limestone $3.14 \%$ and premix $0.90 \%$ ) was fed and controlled individually daily during milking.

The chemical composition of feeds and nutritive value of diet are given in Table 1. RPM, was mixed with a small amount of concentrate before feeding. Animals were fed and milked twice daily at 7.00 and 16.00 . In the last day of experimental period samples from morning and afternoon milkings were pooled according to yield and analysed for protein, fat and lactose contents by infrared analysis (Milkoscan 133B, Foss Electric, Denmark) and for amino acids using an automatic amino acid analyser (T-339, Microtechna, Czech Republic) according to methods given by Urbaniak et al. (2001). Casein was determined according to the method given by Jurczak (1999). Standard methods were used to determine the basic chemical composition of feeds (AOAC, 1990). Acid detergent fibre (ADF) and neutral detergent fibre (NDF) were determined by the method of Van Soest et al. (1991).

Data were analysed by ANOVA using the general linear models procedure of SAS (1985). The main model effects were: goat, period and treatment. Results were expressed as least square means. The significance of differences was accepted at $\mathrm{P}<0.05$. 
TABLE 1

Chemical composition of feeds and nutritive value of basal ration

\begin{tabular}{|c|c|c|c|c|c|c|}
\hline \multirow[b]{2}{*}{ Components } & \multicolumn{4}{|c|}{ Chemical composition, g/kg DM } & \multirow{2}{*}{\multicolumn{2}{|c|}{$\begin{array}{l}\text { Nutritive value } \\
\text { of basal ration }\end{array}$}} \\
\hline & $\begin{array}{l}\text { maize } \\
\text { silage }\end{array}$ & $\begin{array}{l}\text { sugar } \\
\text { beets }\end{array}$ & $\begin{array}{c}\text { meadow } \\
\text { hay }\end{array}$ & concentrate & & \\
\hline Dry matter & 291.4 & 152.3 & 919.5 & 896.2 & $\mathrm{UFL} / \mathrm{kg} \mathrm{DM}$ & 0.83 \\
\hline Crude protein & 72.4 & 134.6 & 95.8 & 187.9 & $\mathrm{PDI}(\mathrm{E}), \mathrm{g} / \mathrm{kg} \mathrm{DM}$ & 85 \\
\hline Ether extract & 18.9 & 44.6 & 8.8 & 34.6 & PDI $(N), g / k g ~ D M$ & 82 \\
\hline Crude fibre & 288.3 & 69.6 & 369.8 & 71.3 & Met $\mathrm{Dl}, \% \mathrm{PDI}^{1}$ & 1.87 \\
\hline $\mathrm{N}$-free extractives & 572.0 & 522.7 & 440.0 & 630.7 & Lys DI, \% $\mathrm{PDI}^{1}$ & 6.90 \\
\hline Crude ash & 48.4 & 228.5 & 85.6 & 75.5 & & \\
\hline Acid detergent fibre & 313.3 & 83.4 & 383.6 & 97.6 & & \\
\hline Neutral detergent fibre & 566.2 & 141.8 & 680.8 & 257.3 & & \\
\hline
\end{tabular}

' calculated using an AA profiling method (Rulquin et al., 1998)

\section{RESULTS}

Supplementation of protected Met did not have a significant effect on milk production and composition (Table 2), although a trend for the increase in milk and milk fat yield and milk protein content and yield were observed with the increase of RPM supplementation up to $3 \mathrm{~g} / \mathrm{d}$. A higher addition of RPM led to a decline in values of the examined parameters. Milk fat, lactose and casein content varied inconsistently. Also AA composition of milk protein (Table 3) was not affect by Met supplementation.

TABLE 2

The effect of rumen protected methionine on milk yield and its composition

\begin{tabular}{lrrrrrr}
\hline \multirow{2}{*}{ Indices } & \multicolumn{5}{c}{ Smartamine ${ }^{\mathrm{TM} M} \mathrm{~g} / \mathrm{d}$} \\
\cline { 2 - 7 } & \multicolumn{1}{c}{0} & \multicolumn{1}{c}{1.5} & \multicolumn{1}{c}{3} & 4.5 & \multicolumn{1}{c}{$\mathrm{SE}^{\mathrm{a}}$} & $\mathrm{P}$ \\
\hline Yield, g/d & & & & & \\
milk & 1882.0 & 2078.0 & 2108.0 & 1988.0 & 52.8 & $\mathrm{NS}$ \\
protein & 48.7 & 55.9 & 57.3 & 52.6 & 2.9 & $\mathrm{NS}$ \\
fat & 61.0 & 64.4 & 64.9 & 63.8 & 4.3 & $\mathrm{NS}$ \\
& & & & & & \\
Composition, g/100g & & & & & & \\
protein & 2.59 & 2.69 & 2.72 & 2.65 & 0.16 & $\mathrm{NS}$ \\
fat & 3.24 & 3.10 & 3.08 & 3.21 & 0.49 & $\mathrm{NS}$ \\
lactose & 4.29 & 4.04 & 4.31 & 4.25 & 0.18 & $\mathrm{NS}$ \\
cascin & 2.08 & 2.11 & 2.15 & 2.06 & 0.18 & $\mathrm{NS}$ \\
\hline
\end{tabular}

a standard error

NS - non-significant 
TABLE 3 The effect of methionine infusion on amino acid (AA) composition of milk protein, g AA/ $100 \mathrm{~g}$ protein

\begin{tabular}{|c|c|c|c|c|c|c|}
\hline \multirow{2}{*}{ Amino acid } & \multicolumn{4}{|c|}{ Smartamine ${ }^{\mathrm{TM}} \mathrm{M}, \mathrm{g} / \mathrm{d}$} & \multirow{2}{*}{$\mathrm{SE}^{\mathrm{a}}$} & \multirow{2}{*}{$\mathrm{P}$} \\
\hline & 0 & 1.5 & 3 & 4.5 & & \\
\hline \multicolumn{7}{|l|}{ EAA* $^{*}$} \\
\hline Lys & 6.4 & 6.9 & 6.6 & 6.4 & bset & NS \\
\hline His & 3.2 & 3.1 & 3.0 & 3.0 & 0.31 & NS \\
\hline Thr & 4.6 & 4.5 & 4.5 & 4.5 & $828=$ & NS \\
\hline Arg & 2.4 & 2.5 & 3.1 & 2.5 & 0.552 & NS \\
\hline Val & 5.8 & 5.7 & 5.6 & 5.8 & 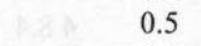 & NS \\
\hline Met & 2.3 & 2.4 & 2.5 & 2.5 & 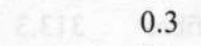 & NS \\
\hline Cys & 1.0 & 1.0 & 1.2 & 1.0 & 0.1 & NS \\
\hline Ile & 4.2 & 3.9 & 3.9 & 4.3 & 0.2 & NS \\
\hline Leu & 8.0 & 7.4 & 7.7 & 8.6 & 0.4 & NS \\
\hline Phe & 4.7 & 3.9 & 4.1 & 4.6 & 0.4 & NS \\
\hline \multicolumn{7}{|l|}{ NEAA** } \\
\hline Tyr & 3.5 & 3.3 & 3.7 & 3.6 & 0.4 & NS \\
\hline Asp & 6.8 & 6.7 & 6.8 & 6.3 & 0.2 & NS \\
\hline Glu & 21.1 & 21.6 & 21.4 & 21.1 & 0.2 & NS \\
\hline Ser & 4.3 & 4.3 & 4.7 & 4.3 & 0.2 & NS \\
\hline Gly & 1.4 & 1.4 & 1.5 & 1.5 & 0.1 & NS \\
\hline Ala & 2.6 & 2.7 & 3.1 & 2.7 & 0.2 & NS \\
\hline Pro & 12.8 & 13.4 & 12.3 & 11.2 & 1.6 & NS \\
\hline Total EAA & 42.6 & 41.3 & 42.2 & 43.2 & 1.9 & NS \\
\hline Total NEAA & 52.5 & 53.4 & 53.5 & 50.7 & 1.9 & NS \\
\hline Total AA*** & 95.1 & 94.7 & 95.7 & 93.9 & 0.3 & NS \\
\hline
\end{tabular}

*EAA - essential amino acids, ${ }^{* * N E A A ~-~ n o n-~ e s s e n t i a l ~ a m i n o ~ a c i d s, ~}{ }^{* * *}$ TAA - total amino acids

a standard error; NS - non-significant

\section{DISCUSSION}

The performed experiments dealt with the influence of RPM for lactating goats fed a mixed roughage-based diet on milk yield and composition. Met and Lys concentrations in the total AA passing to the small intestine calculated using an AA profiling method (Rulquin et al., 1998) amounted to 1.87 and $6.90 \%$, respectively. The addition of RPM (Smartamine ${ }^{\mathrm{TM}}$ ) increased the concentration of Met in the duodenal digesta protein of goats in individual groups up to 2.56, 3.22 and $3.86 \%$, respectively.

There is no data in the available literature dealing with the effect of protected methionine on lactating parameters of goats. Majority of these types of investiga- 
tions were carried out on dairy cows. No significant increase in milk yield was found in cows fed maize silage and hay-based diets (Schingoethe et al., 1988), in cows fed lucerne-maize silage-based diets (Armentano et al., 1997; Overton et al., 1998) which were supplemented with protected Met and also when cows were given grass silage-based diets supplemented with Met (Chillard et al., 1995) postruminally. It is generally believed that substantial milk yield increases can be achieved in the early lactation but not in mid- or late lactation (Rulquin, 1992). In our studies, goats were beyond their lactation peak and this may explain lack of significant differences in their milk yield.

Lactation parameters which respond to limiting AA supplementation most frequently are milk protein content and yield. However, in our experiments we did not observe a significant increase of the above parameters, contrary to studies in which grass silage or maize silage-based diets were post-ruminally supplemented with Met (Pisulewski et al., 1996; Rulquin and Delaby, 1997) or when protected Met and Lys were added to a maize-based diet (Armentano et al., 1993). Similarly to our experiment, also Overton et al. (1998) and Pisulewski and Kowalski (1999) did not find a significant increase in milk protein yield as well as protein and casein content in milk.

The diet formulated for this experiment covered the INRA (1989) net energy (UFL) and protein (PDI) recommendations. It can, therefore, be assumed that the basal diet, in conditions of this experiment, provided the animals also with sufficient quantities of Met absorbable in the small intestine.

Fat yield and content in milk in our experiment were not treatment-depend which is in agreement with results of several similar investigations (Chillard et al., 1995). The lack of influence of increasing RPMH levels on AA milk protein composition observed in these investigations corresponds with results of similar studies conducted on lactating ewes whose diet was supplemented with protected Met (Lynch et al., 1991). It is generally believed that AA milk protein composition is relatively stable and only slightly depends on nutritional factors.

Summing up, it can be concluded that, in conditions of this experiment, when the basal diet provided the recommended quantity of energy (UFL) and protein (PDI), methionine was not an amino acid which limited milk yield and composition in lactating goats. 


\section{REFERENCES}

AOAC, 1990. Association of Official Analytical Chemists. Official Methods of Analysis. $16^{\text {th }}$ Edition. Arlington, VA

Armentano L.E., Swain S.M., Ducharme G.A., 1993. Lactation response to ruminally protected methionine and lysine at two amounts of ruminally available nitrogen. J. Dairy Sci. 76, 2963-2969

Armentano L.E., Bertics S.J., Ducharme G.A., 1997. Response of lactating cows to methionine or methionine plus lysine added to high protein diets based on alfalfa and heated soybeans. J. Dairy Sci. 80, 1194-1199

Bequtte B. J., Backwell F. R. C., MacRae J. C., Lobley G. E., Crompton L. A., Metacalf J. A., Sutton J.D., 1996. Effect of intravenous amino acids infusion on leucine oxidation accros the mammary gland of the lactating goats. J. Dairy Sci. 79, 2217-2224

Chillard Y., Rouel J., Ollier A., Bony J., Tanan K., Sloan B.K., 1995. Limitations indigestible methionine in the intestine (MetDI) for milk protein secretion in dairy cows fed a ration based on grass silage. Anim. Sci. 60, 553 (Abstr.)

INRA, 1989. Ruminant Nutrition: Recommended Allowances and Feed Tables. R. Jarrige (Editor). John Libbey Eurotext, London, pp. 289

Jurczak M.E., 1999. Milk production, survay processing (in Polish). Warsaw Agricultural University Press, Warszawa (Poland), pp. 155

La Henaff L., Rulquin H., Vérité R., 1990. Lactational responses to postruminal infusions of amino acids in dairy cows fed maize silage, hay or grass silage. Reprod. Nutr. Develop. 30, Suppl. 2, 273 (Abstr.)

Lynch G.P., Jackson J.R., Elsasser T.H., Rumsey T.S., Camp M.J., 1991. Nitrogen metabolism of lactating ewes fed rumen-protected methionine and lysine. J. Dairy Sci. 74, 2268-2276

Overton T.R., Emmert L.S., Clark J.H., 1998. Effects of source of carbohydrate and protein and rumen-protected methionine on performance of cows. J. Dairy Sci. 81, 221-228

Pacheco-Rios D., McNabb W.C., Hill J.P., Barry T.N., MacKenzie D.D.S., 1997. The effects of methionine supplementation upon milk composition and production of dairy cows in latc lactation. Nutr. Soc. NZ 22, 184-191

Pisulewski P.M., Kowalski Z.M., 1999. The effect of protected lysine and methionine on milk yield and its composition in lactating dairy cows fed grass silage-based rations. J. Anim. Feed Sci. 8, 341-353

Pisulewski P.M., Rulquin H., Peyraud J.L. Vérité R., 1996. Lactational and systemic responses of dairy cows to postruminal infusions of increasing amounts of methionine. J. Dairy Sci. 79, 1781-1791

Rulquin H., 1992. Intérêts et limites d'un apport de methionine et de lysine dans l'alimentation des vaches laitières. INRA Prod. Anim. 5, 29-36

Rulquin H., Delaby L., 1997. Effects of the energy balance of dairy cows on lactational response to rumen- protected methionine. J. Dairy Sci. 80, 2513-1522

Rulquin H., Guinard J., Vérité R., 1998. Variation of anino acid content in the small intestine digesta: development of a prediction model. Livest. Prod. Sci. 53,1-13

Rulquin H., Pisulewski P. M., Vérité R., Guinard J., 1993. Milk production and composition as a function of postruminal lysine and methionine supply: a nutrient-response approach. Livest. Prod. Sci. 37, 69-90

SAS, 1985. SAS user's guide : Statistics Version 5 SAS Institute Inc., Cary, NC

Shingoethe D.J., Casper D.P., Yang C., Illg D.J., Sommerfeldt J. L., Mueller C.R., 1988. Lactational response to soybean meal, heated soybean meal, and extruded soybeans with ruminally protected methionine. J. Dairy Sci. 71, 173-179 
Sloan B.K., 1997. Developments in amino acid nutrition of dairy cows. In: P.C. Garnsworthy J. Wiseman (Editors). Recent Advances in Animal Nutrition. Nottingham University Press, Nottingham, pp. 167-198

Urbaniak M., Król H., Zawadzka B., Kulik M., Frankiewicz A., Lyczyński A., Pospiech E., Wasilewski Z., 200I. Effects of soyabean meal, rapeseed meal and extruded field bean seeds on duodenal amino acids supply. J. Anim. Feed Sci. 10 (in press)

Van Soest P.J., Robertson J.B., Lewis B.A., 1991. Methods of dietary fiber, natural detergent fiber and non- starch polysacharides in relation to animal nutrition. J. Dairy Sci. 74, 3583-3593

\section{STRESZCZENIE}

Dodatek chronionej metioniny dla kóz mlecznych żywionych dawką z udzialem różnych pasz objętościowych

Dwadzieścia kóz rasy białej uszlachetnionej podzielono metodą analogów na cztery grupy i żywiono dawką podstawową składającą się z różnych pasz objętościowych (kiszonka z kukurydzy, buraki cukrowe i siano ląkowe) oraz paszy treściwej z udziałem poekstrakcyjnych śrut: sojowej i rzepakowej. Zwierzęta z poszczególnych grup otrzymywały dodatek $0,1.5,3.0 \mathrm{i} 4.5 \mathrm{~g} / \mathrm{d}$ chronionej metioniny (Smartamine ${ }^{\mathrm{TM} M}$ ).

Nie stwierdzono istotnych różnic w wydajności i składzie mleka. Obserwowano jednak tendencję wzrostu dziennej wydajności mleka i tłuszczu oraz zawartości i wydajności białka mleka u kóz wraz ze wzrostem dodatku chronionej metioniny do $3 \mathrm{~g} / \mathrm{d}$. Skład aminokwasowy białka mleka nie różnił się istotnie pomiędzy grupami. 